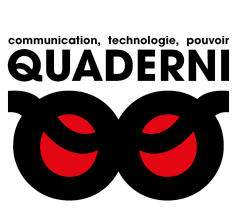

\title{
Quaderni
}

Communication, technologies, pouvoir

\section{Social networks of death: conspiracy panics and professional journalistic ethics in the post-Soviet Russia}

Ilya Yablokov

\section{(2) OpenEdition}

Journals

Electronic version

URL: https://journals.openedition.org/quaderni/1113

DOI: $10.4000 /$ quaderni. 1113

ISSN: 2105-2956

Publisher

Les éditions de la Maison des sciences de l'Homme

Printed version

Date of publication: 5 October 2017

Number of pages: 53-62

Electronic reference

Ilya Yablokov, "Social networks of death: conspiracy panics and professional journalistic ethics in the post-Soviet Russia", Quaderni [Online], 94 | Automne 2017, Online since 05 October 2019, connection on 22 July 2021. URL: http://journals.openedition.org/quaderni/1113 ; DOI: https://doi.org/10.4000/ quaderni.1113 


\section{$D$ ossier}

\section{Social networks of death :}

conspiracy

panics and

professional

journalistic

ethics in the post-Soviet

Russia

\section{Ilya \\ Yablokov}

Chercheur Associé et enseignant

Université de Leeds

United Kindom
On 16 May 2016 Russia's leading investigative newspaper Novaya Gazeta published an article on the suicides of teenagers across the Russian Federation. The article entitled "The Groups of Death" claimed that the Russian social network VKontakte contained a myriad of groups for teenagers that brainwashed young people and pushed them to commit suicide. According to the author, around 130 teenagers died between November 2015 and April 2016 and they were all members of the same communities which were managed by anonymous "puppet masters" that created tasks for teenagers and set the dates of their suicides. ${ }^{1}$

As of July 2017, the article has been accessed by approximately 3.5 millions Internet users, a response that has triggered heated debates and legislative amendments. Galina Mursalieva, the author of the piece, has released a book based on the article that has promoted the alarmist argument that the Internet is dangerous for Russian teenagers. ${ }^{2}$ However, what strikes the reader about the original text is the strong conspiratorial spirit that frames the main argument of the article and how key conspiracy theories are for the construction of the public issue: the teenage suicides and the growing influence of the Internet. The author triggers moral panics around the Internet. She demands the law enforcement agencies to intervene and close the "suicidal" groups, arrest the founders and protect young people from the powerful, faceless forces. Still, the argument in which these conspiratorial allegations are couched lacks any internal logic, and they are criticized by fellow journalists who accuse the media outlet of a tremendous lack of professionalism and an endorsement of conspiracy theories. What has triggered this debate, why has a fierce 
argument divided the professional community and what can be learnt from this case about the Russian media environment?

\section{The Mystery of Russian Teenage Suicides}

"This text has to be read by ALL PARENTS" Mursalieva declares in the introduction to her piece. The lead of the article states: "[Somebody] is systematically and consistently working with young people on social networks, pushing them over the edge." ${ }^{3}$ The bottom line of the piece: Russian social networks are full of secret communities managed by anonymous villains that draw children into role play games that are supposed to end in suicide.

Mursalieva is known for her alarmist attacks against the Internet. In her 2006 book she argued that the Internet is fatally dangerous for Russian youngsters. ${ }^{4}$ However, the new article in May 2016 has attracted more readers. Mursalieva's argument has also seriously evolved and adopted clearly conspiratorial features. It has embraced the notion that anonymous adults, who control the Internet, manage the online groups and indoctrinate teenagers to commit suicide. After joining these groups youngsters play online games that step by step draw them ever deeper into group chat where teenagers must answer questions and decipher mysteries. Parents are not able to comprehend how these networks operate and what their children are discussing and therefore they struggle to understand what is happening to them. Some parents and the author see the social networks as a weird amalgam of signs, strange words and references to various religious cults and sects.
At the final stage of this game teenagers are given 50 days before committing suicide. According to the author and the mother of Angelina Davydova her daughter had shown no signs of depression or mental illness before suicide. After Angelina's death her mother explored these "groups of death" and discovered that at the final stages of the game teenagers are asked to wake up at 4:20 in the morning and look for the meaning of strange symbols. Mursalieva writes: "That is a vulgar manipulation of ideas and invented symbols, that were turned into a meme by the unknown puppet masters. In a nutshell, it's rubbish. However, youngsters who sleep only half the night... take it for granted." ${ }^{5}$

The article claims that the online campaign to provoke teenage suicide began with the death of a certain Rina from Ussuriisk, a Russian city in the Far East. Her photo after the suicide, according to the author and her interviewees, has been spread in these "suicide groups" deliberately. Her mother claimed that the day of her daughter's death was set by "someone" and that she had been given the order to commit suicide by phone. All contributors to discussion about these "suicide groups" note that for their now-dead children, the photo of Rina became an icon that was quickly spread around numerous groups by the very same people who had killed their children.

The conclusion of the article is straightforward: the admins of online communities are petty criminals who work for the benefit of an unknown and invisible "Devil". Russian parents are dealing with a well-designed mechanism to destroy young people, one that brainwashes their children and relentlessly pushes them to suicide. In her 
article, Mursalieva included a map of Russia with strange symbols that show the cities which the alleged anonymous organizers of the teenage suicides have picked for future teenage deaths. In a fashion traditional for conspiracy theorists, Mursalieva has decoded the map and figured out the cities where the next suicides are to take place. The author has demanded that the law enforcement agencies act rapidly to prevent future suicides; this demand has been supported by the "expert opinions". Two experts, one of whom turned out to be the author's son, a psychologist by training, called for an amendment of the criminal law to introduce harsher punishment for incitement to suicide and harsher policies against the online groups.

As mentioned earlier, the article in Novaya Gazeta sparked a wave of television shows and publications that set off a moral panic of a conspiratorial nature around social networks. The main frame of discussion, orchestrated by the state media and in online space, has disparaged the Internet as a sphere of communication and a social phenomenon. It is an uncontrollable space that endangers Russian children who can't resist the manipulation of anonymous "puppet masters".

\section{"Russians are suffering genocide": the conspiratorial framing of the Russian Internet}

As Jack Bratich argued, conspiracy panics precisely the phenomenon witnessed during the discussed debate - open the portal to understanding the political rationality behind the social and political phenomena of conspiracy theories. ${ }^{6}$ It is important to note that it is not correct to view con- spiracy theories as the tool of crackpots. Current scholarship has already established that they are an important way of discussing societal problems. It is a reaction to a changing landscape of social interaction that puts a person in a situation in which his/her life could be endangered by more powerful actors whose abilities to destroy life through several clicks is hard to underestimate. Uscinsky \& Parent contend, conspiracy theories are a manifestation of the vulnerability of a certain social group that - by spreading conspiracy theories - launches an "early warning system for group security."

Given the intensity of the campaign against "the groups of deaths", the first important observation to be made relates to the suspicions that some Russians have towards the Internet and new technologies.

When we come to the question of urban legends and moral panics, "the Internet" as a concept and space is treated by scholars in a contradictory way. As a space, the Internet seems to be a forum ideal for spreading folklore and oral history. ${ }^{8}$ It is used for studying different social groups representations and narratives and how various stories spread there. ${ }^{9}$ In addition, the Internet has been considered as a springboard for conspiracy theories. ${ }^{10}$ The Internet itself is a subject of these legends and histories: it is an interpretation of a dystopian view of technologies that can be traced back to the beginnings of industrialization. As a technology, the Internet is anticipated either to bring about some social good, such as democracy or equality or, on the contrary, to encourage autocracy, filter bubbles or to provide a space for uncontrolled content or business. ${ }^{11}$ 
The Internet is also an integral part of urban legend that has a special resonance when it relates to children online-practices: teenagers and children are not fully grasped by adults. Children's digital rights and their safety are one of the key issues for studies of the Internet and childhood. The main threats to youngsters that are discussed in such context are pornography, sex between teenagers and Internet addiction. ${ }^{12}$

In that context, the case of anxiety about "the groups of deaths" embraces both these Internet roles. Firstly, it is social networks that serve as the field for gathering folklore and interpretations about the moral panic about teenagers' suicides. Secondly, the Internet itself as a social phenomenon is blamed for drawing youngsters into suicide.

However, the danger that the Internet poses to the Russian authorities in their struggle to control civil activity is another way of discussing the conspiratorial wave of conceptualizations of social networks.

It is worth noting that in the 2000s the Kremlin regularly deployed anti-Western conspiracy theories as a major tool of social cohesion and nation building. ${ }^{13}$ Starting from 2004, when the authorities realized the threat of the color revolutions to the smooth transfer of power from Putin to a successor, anti-Western conspiracy theories were deployed to ruin legitimacy of Vladimir Putin's potential rivals, both inside the country and abroad, ${ }^{14}$ and to justify the gradual authoritarian turn. The constant fear of the Western intrusion in the Russian politics had become a major paradigm to interpret domestic and international developments. The Kremlin assisted the promotion of numerous public intellectuals whose aim was to spread the fears of the Western plot among the Russians, and, thereby, it helped the Kremlin keep the society under control. The Internet, as the freest of all spheres of Russian society in the late Putin's Russia, has inevitably become a major target of repressions.

In the 2000s and especially in the 2010s the Russian authorities have made many attempts to place the online sphere under tight control. ${ }^{15}$ The conspiratorial perception of the Internet is not new to Russia and as the Russian elites have steadily fallen out of favour since 2011 (also as the result of online campaigns by the opposition), a conspiratorial reading of the Internet has been gaining more prominence among the political elites. In 2014 President Vladimir Putin famously called the Internet a "CIA invention" that should be restricted in those countries that fight against American information domination. ${ }^{16}$ The activity of the Russian opposition online has caused several major waves of limitations imposed on users of the Internet by Kremlin deputies. ${ }^{17}$ Hence, by the mid-2010s the media sphere has become largely controlled by the government to prevent any further social and political mobilization organized online. In the last several years state-affiliated political, security, and media elites have penetrated online space, and the role of online space for agenda setting and activism has decreased. ${ }^{18}$

Analysis of the media discussion triggered by the Novaya gazeta article reveals that the conspiratorial pattern chosen by the Russian state-run and state-aligned media deploys conspiracy theories 
as a tool to delegitimize the Internet and to present social networks as launching an "information war" against Russia. As Mark Fenster noted, conspiracy theories can be a powerful tool with which to delegitimize political opponents for they act as slanderous labellization and the means to rally support by creating identities. According to Fenster, conspiracy theories possess an important communicative function; they help unite the audience as "the people" against the imagined "Other" represented by the secretive "ower bloc" This method had already been employed several times by the Kremlin to solve the political crisis and promote its authoritarian agenda. ${ }^{19}$ No surprise that the case of the "groups of death" was realized in a similar fashion.

Media discussion around "the groups of deaths" has revolved around two main topics constantly promoted by the pro-Kremlin speakers, that helped spreading the fears of the Internet and justify further legislative restrictions.

First, state-aligned television companies launched several programs that promoted a conspiratorial reading of online communities. The controversial deputy and anti-LGBT activist Vitalii Milonov called the alleged suicide groups the tool of information warfare against Russia. According to him, the group suicide of teenagers orchestrated by "puppet masters" could have triggered panic in the country and undermined the legitimacy of a government which was unable to protect its citizens. $^{20}$

In the documentary "Where does childhood go?", the television channel NTV argued that Ukrainian hackers are behind "the groups of deaths" - a curious twist in the anti-Ukrainian campaign of previous years. ${ }^{21} \mathrm{~A}$ series of talk shows on television's Channel One consistently developed the Ukrainian motive behind the anti-Russian conspiracy. One of the guests - an activist in the pro-Kremlin "e League of Secure Internet"reiterated the fear that online groups are a mode of information warfare against Russians. ${ }^{22}$ The next show on the topic demonstrated the presenters' interest in further promoting a conspiratorial reading of the story. Both presenters of the show gave considerable time to guests who claimed that online groups have been established by Ukrainian hackers and have penetrated all Russian computers. The anti-Ukrainian stance has been much welcomed and endorsed. Here, conspiratorial statements service social mobilization in support of the government in its attempts to protect the Russian people from foreign online insurgents and use the Ukrainian conflict to put the Internet space under its tight control.

Second, participants in the debate have called for harsher punishment for incitement to suicide that should specifically include online incitement. This amendment must be effected immediately to prevent individuals, allegedly controlled by evil "puppet masters", from meddling in the Russian online sphere and "conspiring" against Russian youth. ${ }^{23}$ Accordingly, conspiratorial notions have been used to legitimize severe measures against online activists who could endorse the anti-government ideas.

It is worth noting that the topic of young peoples' suicides had been brought up in 2012 and that it also received a fair amount of coverage on the major state television channels. Discussions on 
these talk shows did not interpret the teenage suicides as the consequence of a "malign conspiracy". Back then the argument was completely different: young people's addiction to computers resulted from a lack of parental control. ${ }^{24} \mathrm{Hence}$, the dominance of the conspiratorial framing of the Internet in 2016-2017 may be attributed to the increase in the Kremlin's demand to legitimize its authoritarian legislation.

The public discussion in the media that was provoked by the Novaya gazeta article reflected both public anxiety about the growing role of the new technologies in day to day life and the government's concern about social mobilization via the Internet. Supported by state-produced narratives and spread by state-aligned media, conspiratorial notions have been a well-designed instrument to justify state intervention in the online sphere. In March 2017 Vladimir Putin publicly approved amendment to legislation regarding the Internet and the State Parliament has passed new, harsher legislation, seemingly the result of the discussed media campaign triggered by the respected investigative newspaper. ${ }^{25}$ In the 2000s and the 2010s especially Russian authorities very often embarked upon conspiratorial ideas to promote their policies and achieve public mobilization. ${ }^{26}$ Given the nature of the media campaign against social networks framed by conspiratorial ideas, the legislative changes were just a matter of time.

There was, however, another question in this affair: why did one of the best investigative newspapers allow such controversial material to be published?

\section{Professional ethics and journalism in Russia: the case of Novaya gazeta}

The answer is to be found in the dramatic lack of ethical principles in the Russian journalist community. The article by Novaya gazeta had no argument and no hard evidence of who (if anyone at all) stood behind the teenage suicides.

The research suggests that in the post-Soviet period, the Russian journalistic community has failed to establish the professional norms of a community where journalists can operate as gatekeepers, preventing the proliferation of unverified materials. Professional journalistic norms - such as transparent sources, reputation, professional solidarity, evidence-based argument - should protect the mainstream from conspiratorial allegations. ${ }^{27}$ It is safe to argue that nowadays ethical standards are a rare beast in Russian journalism. The number of outlets which follow the rules and fulfil the role of gatekeeper is very small. In the Russian context, journalists attempted but failed to create and promote ethical guidelines among colleagues. ${ }^{28}$ On the contrary, the majority of both rank-and-file and elite Russian journalists, as well as media managers, prefer to work without any guidelines; this allows them to successfully toe the line of the government and release reports and articles that both entertain and create a framing of events and personalities demanded by the Kremlin or the owners of media outlets. ${ }^{29}$ This has resulted from various factors: the pressure of the media owners, the repressive measures of the Kremlin in the 2000s, as well as the absence of professional ethics in the Soviet journalism.

The discussed article revealed this gap and 
highlighted a curious fact: Novaya gazeta, as a leading Russian investigative publication that often unveils the crimes of the Putin regime, had played in the hands of the Kremlin triggering a moral panic that eventually allowed the Kremlin to promote anti-democratic legislation. Another Russian media outlet, Meduza - exceptional in following ethical guidelines - questioned the professionalism of the author of Novaya gazeta, which caused the conflict to escalate further. It argued that the piece dramatically lacked an unbiased character. ${ }^{30}$

Meduza, which is known for its strict internal guidelines and rigorous work on its material had gained the status of the uncompromised beacon of professional ethics; it is this stance that has forced its team to relocate to Latvia to avoid Russian state pressure in 2014. In contrast, Novaya gazeta operates in a much more complicated Russian media environment and in order to survive, its media management has had to cooperate with the law enforcement agencies; and it doesn't have clear professional guidelines that allow it to avoid or minimize conflicts with the Kremlin. ${ }^{31}$ Journalistic investigation of the publication revealed that some junior members of Novaya gazeta's staff have confessed to their interviewees that they have close connections with the law enforcement agencies, who have forced them to divulge information. ${ }^{32}$

All in all, the lack of professional guidelines and the ability to promote any possible material, even if the facts it is based on can hardly be verified, serves as a springboard for conspiracy theories in Russia. Such lack of principles opens the gates to conspiracy theories that in the unhealthy media environment of Putin's Russia serves as a useful tool for social mobilization and a way to legitimize Kremlin policies. In this particular case, the story about "the groups of death", well-written, emotional and appealing to millions of Russian families, triggered public discussion in the media and was used by the Kremlin signified as a grass roots initiative to justify further limitations on the Internet.

The fact of publication in a respected investigative newspaper demonstrates that even critically thinking professionals are vulnerable to conspiratorial thinking. This crucial lack of principles allows Russian journalists to spread conspiracy theories in the media without any professional or reputational consequence. It helps journalists to avoid conflicts with the Kremlin, but, on the other hand, it affects millions of Russian citizens whose reliance on the media is very high, which in turns triggers the moral panic about the new technologies. This not only shapes the national discourse around the Internet but it indirectly helps the government to further curtail freedom of speech.

\section{Remerciements}

The author is grateful to Polina Kolozaridi for useful suggestions during the work on the article. 
$\mathrm{N} \cdot \mathrm{O} \cdot \mathrm{T} \cdot \mathrm{E} \cdot \mathrm{S}$

1. Galina Mursalieva, "Gruppy smerti”, Novaya gazeta, 16 May 2016, available at: https://www.novayagazeta. ru/articles/2016/05/16/68604-gruppy-smerti-18, accessed 20 April 2017.

2. Galina Mursalieva, Deti v seti. Shlem bezopasnosti rebenku v internete, Moscow, AST, 2016.

3. Mursalieva, "Gruppy smerti".

4. Galina Mursalieva, Mezhdutsarstvie v golovakh. Noveishaia istoriia rossiiskogo soznaniia, Moscow, Smysl, 2006.

5. Mursalieva, "Gruppy smerti".

6. ack Bratich, Conspiracy Panics: Political Rationality and Popular Culture, Albany: State University of New York Press, 2008, p. 19.

7. Joseph E. Uscinski and Joseph M. Parent, American Conspiracy Theories, New York: Oxford University Press, 2014, p. 17.

8. Trevor J. Blank, Folklore and the Internet: Vernacular Expression in a Digital World, Logan, Utah: Utah State University Press, 2009; Russel Frank, Newslore: Contemporary Folklore on the Internet, The University press of Mississippi, 2011.

9. Eytan Adar and Lada A. Adamic, "Tracking Information Epidemics in Blogspace”, Proceedings - 2005 IEEE/WIC/ACM International Conference on Web Intelligence, available at: http://cond.org/trackingblogepidemics.pdf, accessed on 28 April 2017.

10. Robert Goldberg, Enemies Within: The Culture of Conspiracy in Modern America, New Haven, Yale University Press, 2001, p. 236; Michael Barkun, A Culture of Conspiracy: Apocalyptic Visions in Contemporary America, Berkeley, University of California Press, 2003, pp.12-14.

11. William H. Dutton, The Oxford Handbook of Internet Studies, Oxford, Oxford University Press,
2013; Evgeny Morozov, The Net Delusion: The Dark Side of Internet Freedom, New York, Public Affairs, 2012.

12. For the study of urban legends among middleclass parents, Roberto H. Potter and Lyndy A. Potter, "The Internet, cyberporn and sexual exploitation of children: media Moral Panics and urban myths for middle-class parents" in Sexuality \& Culture 5, n 3, 2001, pp. 31-48.

13. Ilya Yablokov, Fortress Russia: Conspiracy Theories in the post-Soviet World, Cambridge, Polity Press, 2018.

14. Ilya Yablokov, "Conspiracy Theories as Russia's Public Diplomacy Tool: The Case of 'Russia Today' (RT)", Politics, 35, n 3-4, 2015, pp. 301-315.

15. Andrei Soldatov and Irina Borogan, The Red Web: The Struggle between Russia's Digital Dictators and the New Online Revolutionaries, New York, Public Affairs, 2015.

16. Ewan MacAskill, "Putin calls internet a 'CIA project' renewing fears of web breakup", Guardian, 24 April 2014, available at: https://www.theguardian. com/world/2014/apr/24/vladimir-putin-web-breakupinternet-cia, accessed on 26 April 2017.

17. Julien Nocetti, "Russia's dictatorship-of-the-law's approach to internet policy" in Internet Policy Review 4, n 46 2015, doi: 10.14763/2015.4.380.

18. Gregory Asmolov and Polina Kolozaridi, "The Imaginaries of RuNet: The Change of the Elites and the Construction of Online Space", Russian Politics 2, $\mathrm{n}^{\circ} 1,2017$, p. 78.

19. Ilya Yablokov, "Pussy Riot as Agent Provocateur: Conspiracy Theories and the Media Construction of Nation in Putin's Russia", Nationalities Papers, 42, $\mathrm{n}^{\circ} 4$, pp. 622-636.

20. Anna Sukhodoeva, "Vitalii Milonov: 'Gruppy smerti' - novyi vid informatsionnoy voiny" available at: http://www.spb.kp.ru/daily/26609.7/3625433/, 
accessed on 5 May 2017.

21. Andrei Steniakhin, "Kuda ukhodit detstvo?" NTV, 22 October 2016, available at http://www.ntv.ru/ video/1326262/, accessed on 5 May 2017.

22. "Gruppy smerti", Vremya pokazhet, Channel One, 15 June 2016, available at http://www.1tv.ru/shows/ vremya-pokazhet/vypuski/gruppa-smerti-vremyapokazhet-vypusk-ot-01-03-2017, accessed on 5 May 2017.

23. This argument has been made in several television shows. See, for example, "Gruppy smerti”, Vremya pokazhet, Channel One, 15 June 2016, available at http://www.1tv.ru/shows/vremya-pokazhet/ vypuski/gruppa-smerti-vremya-pokazhet-vypuskot-01-03-2017, accessed on 5 May 2017.

24. See, for example, "Prichinu moei smerti ischite $\mathrm{v}$ Internete", Pust'govoriat, Channel One, 22 February 2012, available at http://www.1tv.ru/shows/pustgovoryat/vypuski-i-dramatichnye-momenty/prichinumoey-smerti-ischite-v-internete-pust-govoryatvypusk-ot-22-02-2012, accessed on 5 May 2017.

25. "Chem plokh zakonoproekt o 'gruppakh smerti",, Meduza, 19 April 2017, available at https://meduza. io/cards/chem-ploh-zakonoproekt-o-gruppah-smerti, accessed on 5 May 2017.

26. See, Ilya Yablokov, Fortress Russia: Conspiracy Theories in Post-Soviet Russia, Cambridge, Polity Press, forthcoming).

27. John Nerone ed., Last Rights: Revisiting Four Theories of the Press, Urbana, University of Illinois Press, 1995.

28. Elisabeth Schimpfossl and Ilya Yablokov, "Power Lost and Freedom Relinquished: Russian Journalists Assessing the First Post-Soviet Decade", Russian Review 76, 2017, pp. 528-531.

29. Elisabeth Schimpfossl and Ilya Yablokov, "Coercion or Conformism? Censorship and Selfcensorship among Russian Media Personalities and reporters in the 2010s", Demokratizatsiya: The Journal of Post-Soviet Democratization 22, $\mathrm{n}^{\circ} 2,2014$, pp. 295-312.

30. 'Piat' glavnykh voprosov k materialu 'Novoi gazety' o podrostkovykh suitsidakh”, Meduza, 17 May 2016, available at https://meduza.io/feature/2016/05/17/ pyat-glavnyh-voprosov-k-materialu-novoy-gazetyo-podrostkovyh-suitsidah, accessed on 5 May 2017. 31. Elisabeth Schimpfossl and Ilya Yablokov, "Media Elites in the Post-Soviet Russia and Their Strategies for Success" Russian Politics 2, n 1, 2017, p. 46. 32. "Tam byli foto porezannykh ruk i pryzhkov s krysh”, Lenta, May 20, 2016, available at https:// lenta.ru/articles/2016/05/20/moremonolof/, accessed on 5 May 2017. 


\section{$R \cdot E ́ \cdot S \cdot U \cdot M \cdot E ́$}

En mai 2016, un important journal russe, Novaya Gazeta, a publié un long article d'investigation intitulé « Les groupes de la mort » traitant de groupes publics sur le réseau social russe Vkontakte ciblant les adolescents et les encourageant au suicide. L'auteur y prétendait que les jeunes Russes étaient tués par une force inconnue qui « tirait les ficelles » de l'internet. Cet article déclencha un large débat public autour des dangers de l'internet pour les jeunes Russes qui déboucha sur l'appel à l'enfermement des fondateurs de ces groupes ainsi qu'une modification législative permettant de poursuivre quiconque encouragerait, favoriserait ou aiderait un suicide. Rapidement, le débat s'est focalisé sur la sphère de l'éthique journalistique dans la mesure où l'auteur des « Groupes de la mort» se vit accusé de violer les règles éthiques du journalisme d'investigation et de propager la peur des nouvelles technologies parmi la population russe. D'une part, la parution de cet article dans un journal d'investigation respecté démontre que même parmi des professionnels capables de réflexions critiques, certains sont vulnérables à la pensée conspirationniste. Non seulement ceci alimente le discours national alarmiste à propos de l'internet, mais, en outre, ceci favorise indirectement les velléités gouvernementales de couper court à la liberté d'expression. D'autre part, la focalisation du débat autour de sphère éthique a permis de souligner le manque de principes professionnels qui permet aux journalistes russes de propager des théories du complot en toute impunité professionnelle ou réputationnelle.

\footnotetext{
Abstract

In May 2016, a leading Russian newspaper Novaya Gazeta published a long investigative piece entitled "The Groups of Death" about public groups in the
}

Russian social network VKontakte which allegedly target teenagers and encourage them to commit suicide. The author claimed that Russian youngsters were being killed by an unknown force that remotely "pulls the strings" on the Internet. The article triggered a massive public debate about the danger of the Internet for young Russians and called for the founders of these groups imprisoned and legislation amended to prosecute anyone who tries to encourage, aid and abet suicide. The debate quickly escalated into the sphere of professional journalistic ethics: the author of "the groups of deaths" pieces was accused of violating the ethical norms of journalistic investigation and thus spreading fear of technological progress among ordinary Russians. On the one hand, the fact of publication in a respected investigative newspaper demonstrates that even critically thinking professionals are vulnerable to conspiratorial thinking. This not only shapes the alarmist national discourse around the Internet but it indirectly helps the government to further curtail freedom of speech. On the other hand, the escalation of the debate to the sphere of ethics uncovers the lack of professional principles that allows Russian journalists to spread conspiracy theories without any professional or reputational reprimand. 